\title{
The new system for promoting news through social media
}

\author{
Anna Puji Lestaria ${ }^{a}$ Sunarto $^{\mathrm{b}}$, Yuliyanto Budi Setiawan $^{\mathrm{c}}$, Darmawan Napitupulu $^{\mathrm{d}}$ and Robbi Rahim $^{\mathrm{e}^{*}}$
}

\author{
${ }^{a}$ Magister Ilmu Komunikasi, UNDIP; Jl. Erlangga Barat VII No. 33, Semarang, Central Java, Indonesia \\ ${ }^{b}$ Departemen Ilmu Komunikasi, FISIP UNDIP; Jl. Prof. H. Soedarto, S.H., Tembalang, Semarang, Central Java, Indonesia \\ cProgram Studi Ilmu Komunikasi, Universitas Semarang; Jl. Soekarno-Hatta, Semarang, Central Java, Indonesia \\ ${ }^{d}$ Indonesian Institute of Sciences; Tangsel, Banten 15314, Indonesia \\ ${ }^{e}$ Sekolah Tinggi Ilmu Manajemen Sukma; Jl. Laksana No. 58 E-F Medan Sumatera Utara, Indonesia \\ CH R O N I C L E \\ A B S T R A C T
}

\begin{tabular}{l}
\hline Article history: \\
Received: May 1, 2018 \\
Received in revised format: June \\
16,2018 \\
Accepted: July 22, 2018 \\
Available online: \\
July 22, 2018 \\
\hline Keywords: \\
New system \\
News \\
Social media
\end{tabular}

\begin{abstract}
This research intends to formulate a new system for the promotion of online news in Indonesia. By using Information System Success Model (DeLone and McLean), this study develops a new system for promoting news through social media. The study focuses on journalistic work with Ethnographic methods from James Spardley. After doing Ethnographic research, this study provides a comprehensive system, which can be used for all online mass media in order to promote the news to get the maximum number of readers.
\end{abstract}

\section{Introduction}

(C) 2018 by the authors; licensee Growing Science, Canada.

In the present era, the development of communication technology plays an important role for the progress of mass media companies. If at the beginning of its development until the end of 2004, the press in Indonesia only rellied on print publications, in the current era, the press is also required to distribute the news in a digital platform. The indicator is the result of a Media Index Survey conducted by Nielsen Media, which shows that the penetration of print media towards its readers has decreased since 2005 . The mass media that 'sell' the news is required to always give priority to the freshness of the information. With the internet, news freshness can be fulfilled, very easily accessible and disseminated, especially for today's society that so gadget minded. The emergence of the internet, along with the presence of computers and smart phones, has been changed the culture of reading the community. Press companies are then required to meet the community culture of digital literacy.

\footnotetext{
* Corresponding author.

E-mail address: usurobbi85@zoho.com (R. Rahim)

(C) 2018 by the authors; licensee Growing Science, Canada doi: $10.5267 /$ j.ijdns.2018.7.002
} 
The Nielsen Consumer and Media View survey until the third quarter of 2017 stated that Indonesian reading habits have been shifting. In 2017, the rate of personal newspaper purchases was only $20 \%$, down compared with 2013, which reached 28\%. Nielsen Indonesia stated that in Indonesia, currently digital media readers are more than the print media. The number of newspaper buyers has steadily declined in the last four years as people think information should be free. In addition, according to the Nielsen Survey, print media is only the fifth choice of the public to obtain information with penetration of $8 \%$. Meanwhile, the first sequence of television is occupied with $96 \%$, followed by billboards on the street $52 \%$, internet usage by $43 \%$, and radio as much as $37 \%$.

One way that can be cured is the press is required to have print and digital platforms. The reason, news consumption today is not the same as pre-internet news when people tune in to events happening around the world through 24-hour television news channels. More recently, a growing number of readers, viewers and listeners are going online for their news (Alejandro, 2010). Even based on data from research ever conducted by Anna Puji Lestari and Sunarto states that not only the younger generation who look for the information through the internet (Lestari and Sunarto, 2018), but also, the baby boomers born between 1946-1964 also read the information through the online news.

The problem that then arises is how the process of loading online news with the presence of social media as one of the media campaign? Current conditions show that internet and communication technologies (ICTs) reshape, reorganize and fundamentally restructure working methods, and ultimately the sectors in which they are used. They offer generic advantages of efficiency gains, information-sharing, communication and faster knowledge accumulation, dissemination and application, in support of the specific purposes for which they are used (UNCTAD, 2003). The development of ICT also requires more creativity media companies distribute news generated through various promotions on the Internet, one of which is through social media. Social media such as Facebook and Twitter are often used as a means of promotion to attract new readers.

Social media encompasses all the services that facilitate creation, sharing and exchange of user-generated content. Besides, social media also drove social change because it empowered the people to express their thoughts and opinions and share them with others. The mass media company used as the object of study in this research is Suaramerdeka.com. Suaramerdeka.com is the first local online media news that is based on print media in Indonesia. Research on social media performed among other studies conducted Phillip Brooker, Julie Barnett, and Timothy Cribbin who do advance an abductively oriented methodological suite designed to explore the construction of phenomena played out through social media. They used software tool - Chorus - to illustrate a visual analytic approach to data. Informed by visual analytic principles, combining two data collection strategies with two analytic modes (Brooker et al., 2016). Research conducted by Elmer (2015) stated that social media can be used as financialized on social media platforms. Such a project may begin by focusing on the terms of publicity, the rules, expectations, and laws that govern the process by which we share the data of the economy that calls forth such as information as a matter of economic design, as an obvious and well-publicized business plan (Elmer, 2015).

The research by Hermida (2015) stated that a greater understanding of what forms of power play-out on social media is essential for illuminating processes of networked gatekeeping, networked framing, and networked sourcing (Hermida, 2015). Assegaff et al. (2017) developed a research model used to investigate social media as a tool for sharing knowledge among academics. That studied in a validated instrument for the purpose of social media success for knowledge sharing (Assegaff et al., 2017). Some of those studies explain the importance of social media for people's lives in the present era. Through social media, communication can be executed widespread and flexible. In relation to journalistic work, it is undeniable that social media has a vital role for the promotion of the latest news broadcast by a mass media company. News promotion through social media can be an effective new system for promoting newly published news. Social media is increasingly being used as an information source, including 
information related to risks and crises. As showed by Westerman et al. (2014) pieces of information are available in social media impact perceptions of source credibility. Today's web and the new media underpin the ability to create instant communication sensations. From Facebook, YouTube, Twitter, and a collection of blogs, a news statement can advance from zero to 20 million viewers overnight.

In what we refer to as the "information age" or "digital age" our technological advancements in the area of ICT have helped overcome limitations of time and space in communication, information sharing and networking. This not only affects how we connect with other people and how we do business (Kamp, 2016). However, in Indonesia, especially in the world of journalism, has not formulated an online news promotion system through social media seriously. Through this study we want to formulate a new system on integrating journalism and social media work to attract potential new readers.

\section{Proposed Model}

\subsection{Theoritical Framework and Model Development}

The use of promotional systems within a mass media company is expected to have a positive impact in order to ensure significant readership over time. In the digital era like today, the competition is so tight. In addition to demands to bring quality news for the community, online mass media are also required to update the news continuously. In order to promote the updating of news for its readers, it needs promotion system through social media continuously and directed.

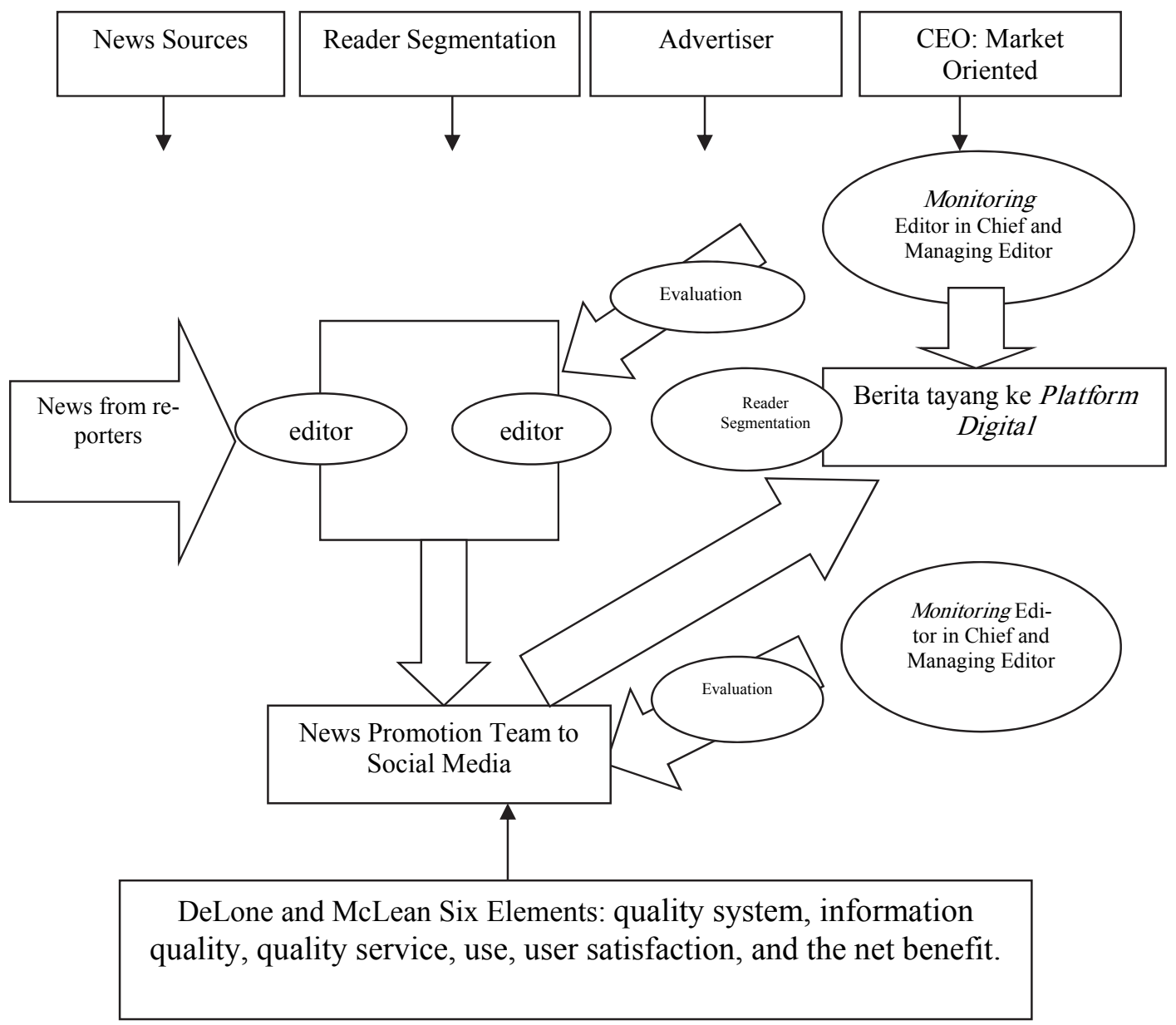

Previously, DeLone and McLean (2003) developed a model that could be used as a guide to implement the Information System (IS) in organization. They poposed six elements related to information System 
successes: quality system, information quality, quality service, use, user satisfaction, and the net benefit. Based on DeLone and Mclean's theory, we developed a new information system for the press. In this study, we formulate a new system that integrates journalism work with social media as a media campaign. In journalistic work, the resulted news is influenced by news sources, readers, advertisers, and market segments the CEO wants. At an online mass media company, the news loading process comes from news reporters' submissions and then they are sent to editors for editing. The news is edited according to the editorial style of the media that contains certain characteristics that distinguish it from other online mass media. The editorial style also considers the market segment for the intended newsreader. Once the news is edited by the editor, then the news is released or broadcast to the online digital media platform. After the broadcast, a special campaign team is required to upload new news that has been aired to social media to capture the reader as much as possible. The process of news promotion system that we formulated, when described are as follows:

\section{Research Method}

In developing a promotional system in online journalism work, we have conducted ethnographic research in one of online news company namely Suaramerdeka.com. We have performed an in-depth interviews with Editor-in-Chief and Executor Editor of the news broadcast policy at Suaramerdeka.com and conducted a newsroom research. Newsroom research is executed by observing the news production process. After an in-depth interview, the next will be data reduction with Spardley's data analysis technique. Spardley (1997) summarized the "Gradual Forward Research Path" consisting of five principles: (1) Researchers are encouraged to use only one data collection technique; (2) Recognize the key steps in the technique, for example 12 key steps in ethnographic interviews from Spardley; (3) Every major step is run in sequence; (4) Practice should always be done; (5) Giving problem solving as its social responsibility, no longer science to science.

\section{Result and Analysis}

Ethnographic methods are chosen because ethnography is a job of describing a culture (Spardley, 2006). Culture referred to in this study is the work culture or routine editorial online mass media companies. The end result of ethnographic making is a verbal description of the cultural situation studied (Spardley, 2006). Ethnographic research in this study was conducted for one week. After a week of ethnography research (7 days) in editorial office suaramerdeka.com and conducted an analysis, we can map the tasks of each personnel involved in the editorial booth suaramerdeka.com. The division of duties of each personnel is prepared based on the policy suaramerdeka.com as a 24-hour cyber newspaper. Editor in Chief stated that suaramerdeka.com is an online media based on local print media of Central Java so that competitors similar to suaramerdeka.com are radarsemarang.com, krjogja.com, radarpekalongan.co.id, harianjogja.com, and kebumenexpress.com. Editor in Chief explained that when compared with the five competitors, suaramerdeka.com fronts in terms of updating local news of Central Java.

Under the editor-in-chief is the Managing Editor. The Managing Editor is the controller of the product to be aired on suaramerdeka.com. While the Coverage Coordinator usually gives more suggestions of the program. Then, the IT department at suaramerdeka.com technically prepares the new channels as needed. The actual news editor at suaramerdeka.com acts as editor. Editor consists of 8 people who each works according to shift work. The actual news editor working per shif is five hours. Within 5 hours they are required to edit and upload 15 to 20 news to their suaramerdeka.com page. While the video editor at suaramerdeka.com are two people who each is required to edit the video of cyber journalists submissions. Each video editor is required to edit and upload 3 to 5 videos per day. Reporter suaramerdeka.com amounted to five people. Each of them is required to submit at least three news and photographs (images) of events covered daily to suaramerdeka.com. In addition, reporters of suaramerdeka.com are required to deliver the video to the video editor to fill out the SMTV channel. The technical search for news reporters at suaramerdeka.com is as follows: 
Journalists receive an assignment from the office to cover an event and journalists are also looking for the latest events, after reporters discovered the latest events, reporters searched for sources to be interviewed. After conducting the interview process, the reporter should then write it down as soon as possible from the field (maximum 30 minutes), then sent immediately to the office email to be edited by the editor in charge.

The entire work of journalism is performed continuously to produce the latest news for readers. In connection with this, Editor in Chief suaramerdeka.com acknowledged that it is necessary promotion through social media to increase the number of readers.

From the results of monitoring researchers, the promotion of news conducted Suaramerdeka.com through social media can increase the number of readers to three to four times. From the Editor in Chief information that if news is not promoted, the readers were very few. In fact, Editor in Chief states, if the news viral in social, can increase readers to tens of times.

From the research we have accomplished, then we may formulate a new system for the promotion of news through social media with accuracy as described earlier. The promotional system through social media that we formulate can be applied for the promotion of news across the mass media online in order to capture the reader as much as possible.

\section{Conclusion}

Based on the research we have accomplished, it can be seen that news promoted through social media can get increase in the number of readers triple, compared with news that did not perform any promotion. In addition, based on the research that has been done, we have also formulated a new system for the promotion of news through social media, accurately. The new system can be applied as part of any online journalism promotion in Indonesia and in the world.

\section{References}

Alejandro, J. (2010). Journalism in the Age of Social Media. In Reuters Institute Fellowship Paper (p. 5). Oxford: University of Oxford.

Assegaff, S., Hendri, Sunoto, A., Yani, H., \& Kisbiyanti, D. (2017). Social Media Success Model for Knowledge Sharing (Scale Development and Validation). Telkomnika, 15(3), 1335-1343. https://doi.org/10.12928/TELKOMNIKA.v15i3.5569

Brooker, P., Barnett, J., \& Cribbin, T. (2016). Doing Social Media Analytics. Big Data \& Society. JulyDecember 2016.

Delone, W. H., \& McLean, E. R. (2003). The DeLone and McLean model of information systems success: a ten-year update. Journal of Management Information Systems, 19(4), 9-30.

Elmer, G. (2015). Going Public on Social Media. Social Media + Society, 1(1), 1-2. https://doi.org/10.1177/2056305115580341

Feuer, L. (1962). What is Alienation? The Career of a Concept. New Politics, 1(3), 117.

Hermida, A. (2015). Power Plays on Social Media. Social Media and Society, 1(April-June 2015), 1-2. https://doi.org/10.1177/2056305115580340

Kamp, M. (2016). Reality Check Assessing The Impact of Social Media on Political Communication and Civic Engagement in Uganda. Kampala, Uganda: Konrad Adenauer Stiftung. Retrieved from www.kas.de/Uganda/en

Lestari, A. P., \& Sunarto. (2018). Digital Gender Gap for Housewives. Jurnal The Messenger, 10(1), 6371. https://doi.org/http://dx.doi.org/10.26623/themessenger.v10i1.729

Spardley, J. P. (1997). Metode Etnografi. Yogyakarta: PT Tiara Wacana.

Spardley, J. P. (2006). Metode Etnografi. Yogyakarta: Tiara Wacana.

UNCTAD. (2003). Information and Communication Technology Development Indices. In United 
Nations Conference on Trade and Development (p. 4). New York and Geneva: United Nations.

Westerman, D., Spence, P. R., \& Van Der Heide, B. (2014). Social Media as Information Source: Recency of Updates and Credibility of Information. Journal of Computer-Mediated Communication, 19(2), 171-183. https://doi.org/10.1111/jcc4.12041

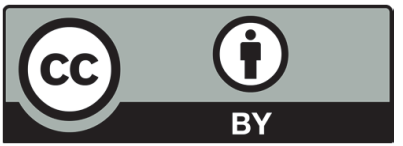

(C) 2018 by the authors; licensee Growing Science, Canada. This is an open access article distributed under the terms and conditions of the Creative Commons Attribution (CCBY) license (http://creativecommons.org/licenses/by/4.0/). 